\title{
The Seville Cathedral altarpiece: a microbiological and chemical survey of the dust
}

\author{
P.M. Martin-Sanchez, B. Hermosin \& C. Saiz-Jimenez \\ Instituto de Recursos Naturales y Agrobiología de Sevilla (IRNAS-CSIC), Sevilla, Spain
}

A.Z. Miller \& M.F.C. Pereira
Instituto Superior Técnico, Centro de Petrologia e Geoquímica (CEPGIST), Lisboa, Portugal

ABSTRACT: The altarpiece of the Seville Cathedral was built between 1481 and 1565 and has a total perimeter of $20.10 \mathrm{~m}$ and $23.41 \mathrm{~m}$ height, which makes this altarpiece the largest in the world. The last restoration was performed in 1977, centered on ensuring its structural stability and consolidation of wood structures and polychromy. A new intervention to appraise the state of conservation is currently in progress. Our study is centered on the assessment of the dust accumulated on the surface including a survey of significant alterations from biological origin. The approach carried out combined molecular biology methods and analytical procedures. The composition of the dust samples is very heterogeneous, comprising mineral particles resulting from the deterioration of the building materials, fragments of decorative elements particularly gold leaf from the gilded wood, products from air pollution (soot), as well as biological fragments of insects, arachnids and bird droppings, in addition to bacteria and fungal spores.

\section{INTRODUCTION}

The Seville Cathedral, constructed in the early 15th century on the site of the Alhama mosque, of which the Giralda minaret still subsists, is one of the world's largest and is considered one of the most important monuments of Christendom. As usual in Gothic cathedrals, the main building material was stone, from various local quarries, in the provinces of Cadiz and Seville, and Portugal (Falcón 1980). The most abundant lithotype used was a yellowish fossiliferous calcarenite of Miocene age, locally known as San Cristóbal stone, and extracted from El Puerto de Santa María quarry (Cádiz).

The altarpiece of the Seville Cathedral was built between 1481 and 1565 and depicts the life of Jesus Christ on carved wood decorated with gold leaf and polychromy. The huge scale of the work, which has a total perimeter of $20.10 \mathrm{~m}$ and $23.41 \mathrm{~m}$ height, makes this altarpiece the largest in the world (Fig. 1a). Several artists were involved in the execution of the altarpiece, such as Pyeter Dancart, Pedro Millán and Maestre Marco, as well as others of unknown identity. However, most of the altarpiece work seems to have been performed by Jorge and Alejo Fernández Alemán. Before the restoration intervention in 1977, serious concerns emerged about the structural condition of the altarpiece, including wood parts in danger of collapse, as well as accumulation of dust on the surface, flaking and lack of adherence of the polychromy and gilding. This restoration intervention was centered on ensuring its structural stability and comprised the consolidation of wood structures and polychromy, as well as the attenuation of losses of different materials.

An intervention to appraise the present state of conservation of the Seville Cathedral altarpiece is currently in progress. Our study is centered on a detailed characterization of the dust accumulated on the surface including a microbiological approach. 


\section{MATERIAL AND METHODS}

Seven dust samples were collected in March 2012 from the surface of the altarpiece (Fig. 1). The scientific approach carried out combined microbiological analyses: isolation of bacteria and fungi on culture media and molecular identification by sequencing of rDNA, and physicochemical analyses: observations by stereomicroscopy and field emission scanning electron microscopy (FESEM), X-ray diffraction (XRD), X-ray fluorescence (XRF) and Fourier-transform infrared spectroscopy (FTIR).

Before analysis, the samples were sieved and divided into five fractions depending on their particle size. Sieves were used with the following pore diameters: 475, 250, 150 and $75 \mu \mathrm{m}$. Stereomicroscopy observations were performed to characterize the physical and morphological properties of the different particles found within the samples. The finest fraction $(<75 \mu \mathrm{m})$ was then analyzed by XRD and XRF. Additionally, other fractions were analyzed by XRD and FTIR.

Aerobiology methodology for identification of airborne bacteria and fungi was described elsewhere (Fernandez-Cortes et al. 2011).
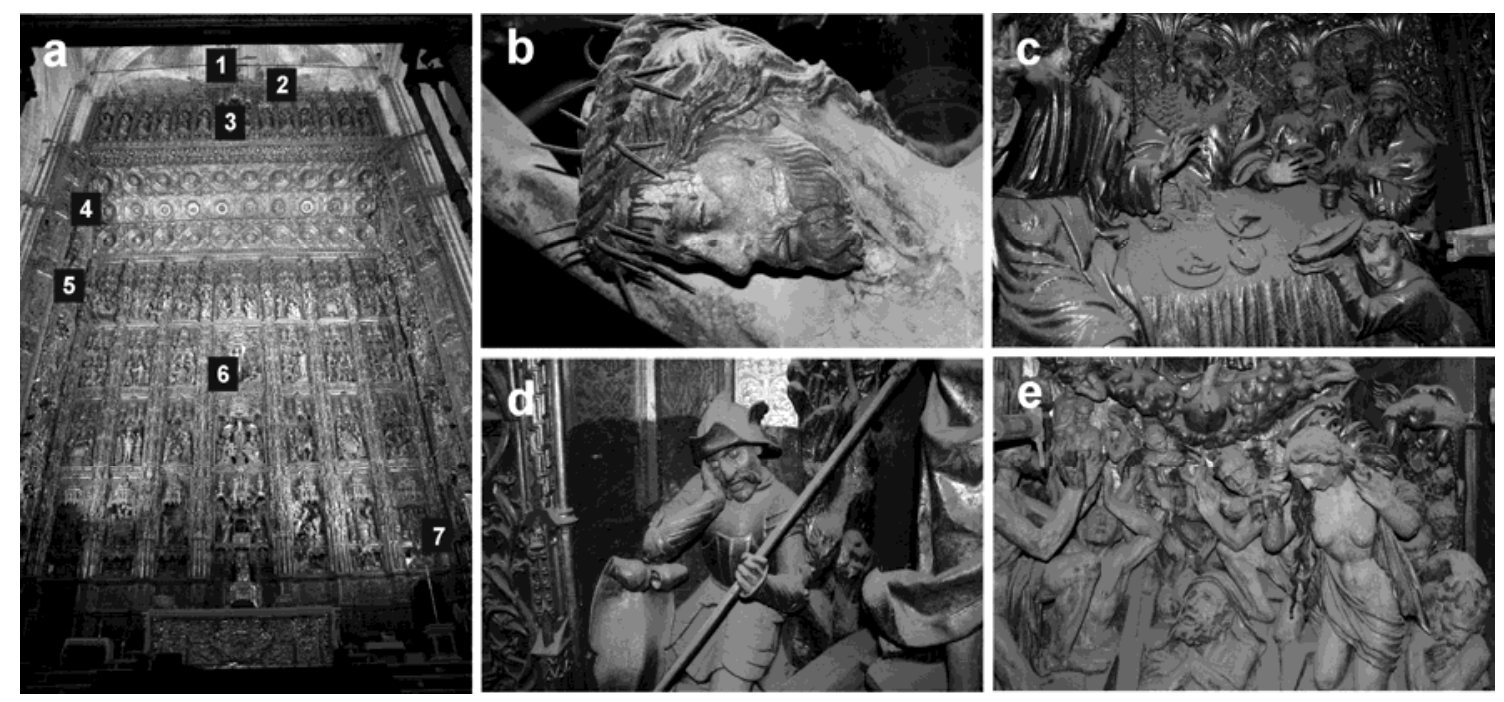

Figure 1. a. The altarpiece of the Seville Cathedral showing the areas where the dust samples (1-7) were collected. b. Cristo del Millón. c. Detail of the María Magdalena unge los pies de Jesucristo panel. d. Detail of the Resurrección de Jesucristo panel. e. Pecado original y expulsión del Paraiso.

\section{RESULTS AND DISCUSION}

\subsection{Microbiological characterization}

All analyzed dust samples contain high amount of microorganisms. High concentrations of bacteria and fungi, between $10^{3}$ and $10^{5}$ colony forming units per gram (cfu/g), were detected (Fig. 2, Table 1). According to the molecular identification, the bacterial were dominated by species of Bacillus, followed by species of Massilia, and a small portion of Staphylococcus. The most abundant fungal species belonged to the genera Cladosporium, Penicillium, Chaetomium, Aspergillus and Trichoderma. These microorganisms have high sporulation rates which facilitate their dispersion. All detected microorganisms have a cosmopolitan distribution and are frequently isolated from any environmental sample.

Table 1. Counting of microbial colonies grown on culture media as colony forming units per gram

\begin{tabular}{lll}
\hline Dust sample & Bacteria (cfu/g)* & Fungi $(\mathrm{cfu} / \mathrm{g})^{*}$ \\
\hline 1 & $1.98 \times 10^{5}$ & $9.28 \times 10^{4}$ \\
2 & $2.78 \times 10^{4}$ & $5.04 \times 10^{3}$ \\
5 & $1.25 \times 10^{5}$ & $1.21 \times 10^{5}$ \\
\hline
\end{tabular}



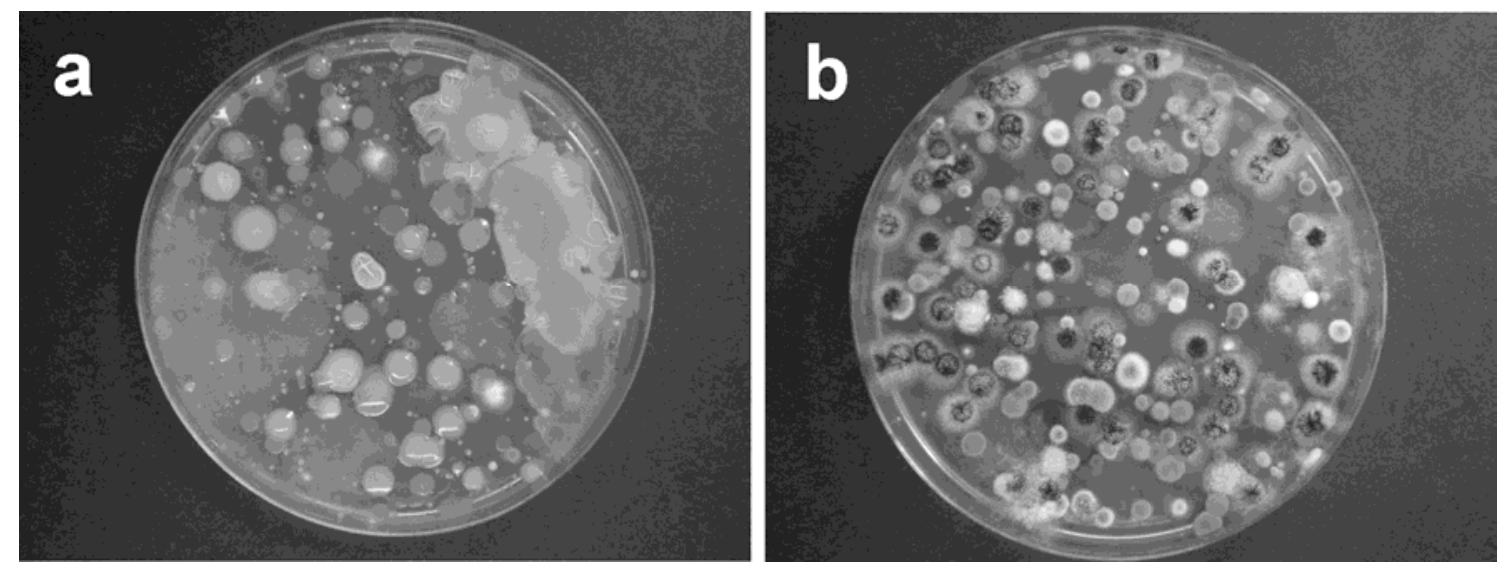

Figure 2. Isolations on culture media. a. Bacterial colonies on Trypticase Soja Agar + Cycloheximide. b. Fungal colonies on Dichloran Rose Bengal Chlortetracycline Agar.

\subsection{Physicochemical characterization}

Stereomicroscopy observations revealed that the composition of the dust samples was very heterogeneous, comprising different components of the building materials (Fig. 3a), fragments of decorative elements particularly gold leafs from the gilded wood and pigments from the polychromy (Fig. 3b-d). Also, abundant fragments of insects, arachnids (Fig. 3e) and bird droppings enriched in uricite were detected (Fig.3f). XRD analysis revealed the presence of calcite, quartz, dolomite, gypsum, halite, illite and anhidrite, which are mostly the mineral constituents of the building materials. A lead chromate, likely $\mathrm{PbCrO}_{4}$, was detected by $\mathrm{XRD}$, suggesting that a yellow pigment was used in the form of chrome yellow on the sculptures of the altarpiece. It must be mentioned that the chrome pigments were in use by 1816 (Douma 2008), which indicates that this pigment was used in conservation intervention performed in 1977 or before, but not at the time of the altarpiece construction. Barium sulfate, $\mathrm{BaSO}_{4}$, was also identified by $\mathrm{XRD}$, which sometimes is used in restoration works as a partial replacement for titanium dioxide in paintings, reducing pigment costs. Moreover, copper resinate was identified by FTIR. In the 15th and 17th centuries artists used copper resinate to add glaze on paintings laying a layer of copper resinate over verdigris to form a deep saturation of green color (Douma 2008).
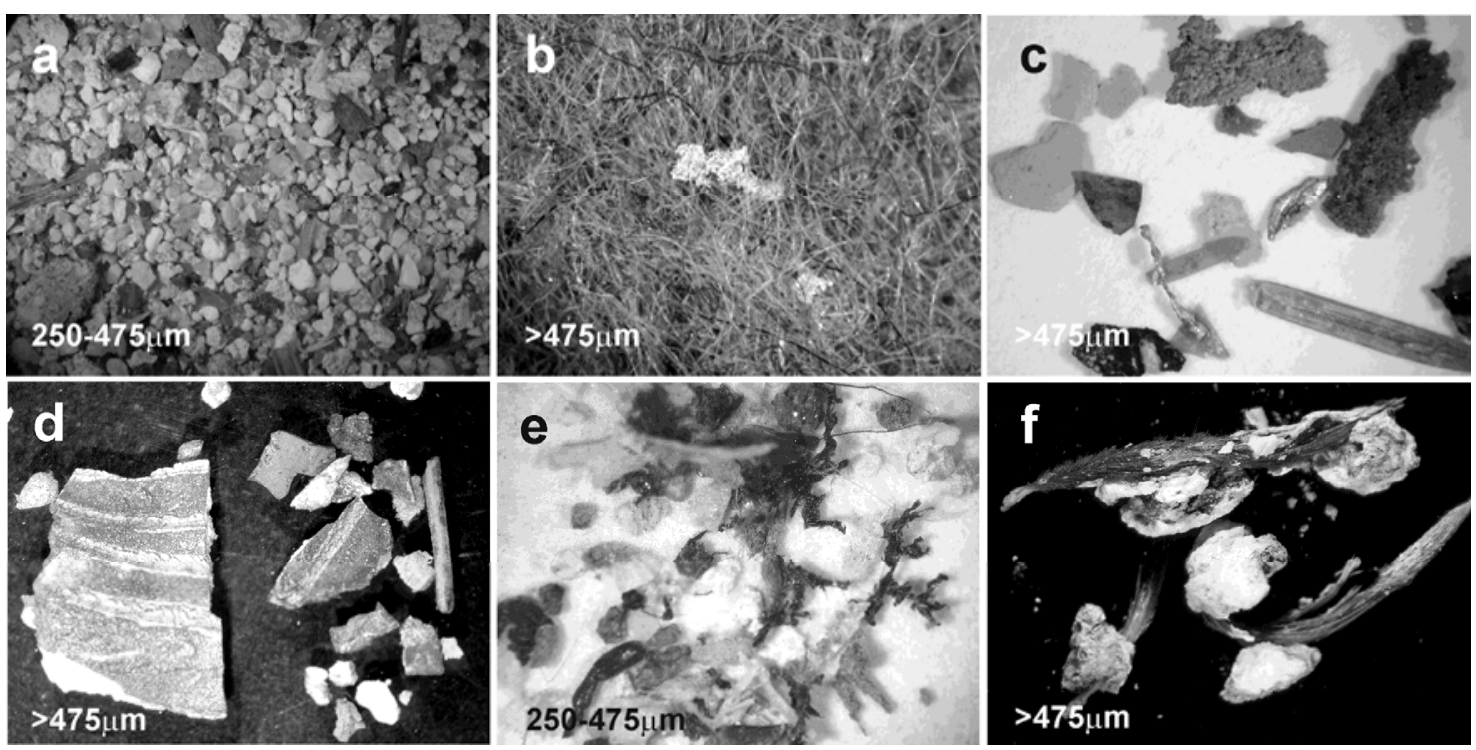

Figure 3. Stereomicroscopy images from different fractions of the dust samples. a. Grains of building materials. b. Fibers and gold leafs. c. Pigments. d. Fragments of gilded wood. e. Fragments of insects and arachnids. f. Bird droppings. 
According to FESEM analysis, abundant pollen grains (Fig. 4a) with different morphologies were observed within the dust samples, together with soot particles probably resulting from air pollution and frequent liturgical activities inside the cathedral. Note that the cathedral is in the centre of the city, an area that until 2006 suffered from intense automotive traffic, which produced an atmosphere of carbon monoxide, sulfur dioxide, soot, hydrocarbons and other substances from vehicle exhausts (Saiz-Jimenez et al. 2004, Reyes et al. 2006). In addition, some diatoms were observed (Fig. 4c) probably derived from the building stones and/or water infiltrations in the roof of the cathedral.
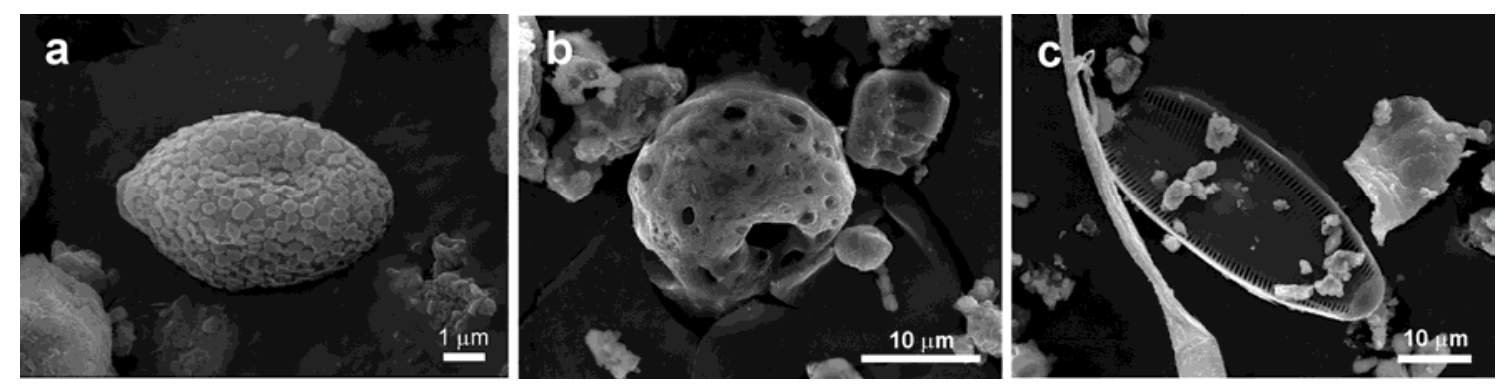

Figure 4. FESEM images of the dust samples depicting: a. Pollen grain, b. Soot particle, and c. Diatom.

\section{CONCLUSIONS}

The dust is mainly composed of stone minerals and decorative elements, denoting an important deterioration of the building materials from the vaults and the altarpiece.

The dust also contain a high microbial contamination specially enriched in bacterial and fungal species, which may cause biodeterioration in case of water availability (high relative humidity, leaks from the vault, etc.) on the different materials and would represent a risk for the conservation of the artworks. Insects and arachnids are also common in the dust.

It is recommended a cleaning of the altarpiece dirtiness. The opening of doors in the upper terraces should be avoided and a control of the opening time in the main gates to decrease dust concentration inside the Cathedral is needed. Furthermore, regular maintenance seems necessary due to the high concentration of dust accumulated over extended periods of time.

\section{ACKNOWLEDGEMENTS}

The Cabildo Catedral de Sevilla supported this research through Agora S.L. The postdoctoral fellowship granted by the Portuguese Fundação para a Ciência e a Tecnologia to A.Z.M. (SFRH/BPD/63836/2009) is acknowledged. CEPGIST work was supported by PTDC/EATEAT/116700/2010 and PEst-OE/CTE/UI0098/2011.

\section{REFERENCES}

Douma, M. 2008. Pigments through the Ages. [online] Available at: http://www.webexhibits.org/pigments/intro/pigments.html [accessed: 28/09/2012]

Falcón, T. 1980. La Catedral de Sevilla. Estudio Arquitectónico. Sevilla: Grafitalia.

Fernandez-Cortes, A., Cuezva, S., Sanchez-Moral, S., Porca, E., Jurado, V. \& Saiz-Jimenez, C. 2011. Detection of human-induced environmental disturbances in a show cave. Environmental Science and Pollution Research 18: 1037-1045.

Reyes, J., Hermosin, B. \& Saiz-Jimenez, C. 2006. Organic composition of Seville aerosols. Organic Geochemistry 37: 2019-2025.

Saiz-Jimenez, C., Brimblecombe, P., Camuffo, D., Lefèvre, R.-A. \& Van Grieken, R. 2004. Damages caused to European monuments by air pollution: assessment and preventive measures. In C. SaizJimenez (ed), Air Pollution and Cultural Heritage: 91-110. Lisse: Balkema. 